\title{
Value Preposition Canvas Design for Herbal Tea Product BEETEA
}

\author{
Ani Nuraisyah* \\ School of Business \\ $I P B$ University \\ Bogor, Indonesia \\ anynuraisyah@apps.ipb.ac.id
}

\author{
M. Syamsul Ma'arif \\ School of Business \\ IPB University \\ Bogor, Indonesia \\ syamsu14958@gmail.com
}

\author{
Okhy Widhasari \\ School of Business \\ IPB University \\ Bogor, Indonesia \\ okhy091096@gmail.com
}

\begin{abstract}
This research aims to design the value proposition canvas for herbal tea's product BEETEA with one approach is action research. Value proposition canvas for BEETEA is formed based on several stages, including analyzing the value proposition canvas 0 by conducting in-depth interviews with the owner of the BEETEA to obtain the insights from the business owner. After that an in-depth interview was conducted with consumers intended to create the empathy map from BEETEA's consumers and then the empathy map is used to form the value proposition canvas 1 , for the last step is to weight the main value for BEETEA's consumers as a result of the research and for input to the producers. The results of this study show that consumers want a variety of flavors and scents. Other than that the consumers also want the addition of features such as straps o tea bags that will make it easier for the consumers to brew the BEETEA and also to add the concentration of BEETEA's tea color to make it more attractive for the consumers.
\end{abstract}

Keywords: value preposition, business model canvas, herbal tea

\section{INTRODUCTION}

Tea is one of the most consumed beverage in the world besides mineral water [1] and tea beverages are consumed mainly because of the unique aroma and taste it contains [2]. Tisanes or herbal tea is one type of tea beverages that is in great demand and develops not only in Indonesia but throughout the world. Tisanes or herbal tea is a type of tea beverages that is the result of boiling herbal ingredients other than Camellia sinesis leaves [3]. Tisanes are categorized based on the origin of its raw materials, which include those from leaves, flowers, roots, bark, fruit or berries, to spices. The development of tisanes in Indonesia according to [4] began in 2012 where sixteen people began developing Rosella Tea business in various locations in Indonesia. Just like Rosella, beetroot can also be used as a derivative product in the form of instant tea that can be classified into a group of tisanes.

All In Red is one of the SMEs who not only producing beetroot in the form of fresh products but also produces its derivative products in the form of instant tea bags with the BEETEA brand. BEETEA is one type of tisanes in Indonesia which originates from one hundred percent of beetroot. BEETEA is packaged in form of tea bag weighing one gram each. BEETEA is one of the instant teabag products that promotes the habit of drinking tea for particular reason (tea with purpose) for example, reasons of health and relaxation, and rejuvenation process [5]. But unfortunately, the value embedded in BEETEA products has not been fully absorbed by consumers.

A product launched to the market needs to provide solution for consumers as well as uniqueness and creativity point [6]. Therefore, this research will focus on looking at the compatibility between Value Propositions attached to the product and the Customer Segments they are targeting, then formulating it into a Value Proposition Canvas that is better suited for BEETEA products. The objectives of this study are (1) Analyzing the BEETEA's value proposition canvas at present (2) Analyzing the customer segment blocks on the value proposition canvas for BEETEA products (3) Designing the BEETEA product value proposition canvas in the future.

\section{MATERIAL AND METHODS}

\section{A. Problems and Hypothesis}

Besides providing solution for the customers, having unique value proposition as well as creativity in the products and the marketings are what makes a product launch successful. Especially the creativity point become one of the keys contained in the value proposition or value that will be offered to consumers. Based on the background above, the problems in this study can be formulated to:

1) What is the value proposition canvas on BEETEA products today?

2) How the analysis of the Customer Segment block on the Value Proposition Canvas for BEETEA products works?

3) What is the design of the value proposition canvas on BEETEA herbal tea products in the future?

\section{B. Methodology}

The study started by analyzing VPC 0 obtained based on insights from BEETEA producers by conducting interviews 
with them. Subsequently conducted in-depth interviews with BEETEA consumers, which the results are translated into an empathy maps, which can then be described as VPC 1 of BEETEA products. Then, the weighting is done with Eckenrode method which can bring up new values on VPC 2 that is more suitable for BEETEA Herbal Tea products.

\section{RESULTS AND DISCUSSION}

Value Proposition Canvas according to [7] is a tool to assist in the process of creating value for consumers that in accordance with consumers' desires. Desires in question are functionality, social desires, emotions, and cost savings. The purpose of VPC is to help make good maps of detail in a simple but powerful and also structured fashion. Through visualization, the company producing the product will have better strategic skills and can also prepare it into two VPC blocks.

Based on research conducted, it can be concluded that Analysis of Value Proposition Canvas 0 on in-depth interviews with BEETEA producers, All In Red, produces an overview of Value Propositions and Customer Segments that can be depicted as the current VPC of BEETEA. After that, the Customer Segments analysis is carried out to get the full picture of Empathy Map from consumers which is then translated into VPC 1 of BEETEA products. In the Customer Segments or Customer Profiling block, BEETEA or All In Red producers chooses 5 (five) points that will become the priority of developing values which will be translated into VPC 2.

Fig. 1 shows Value Proposition Canvas 2 is a picture of VPC that fits between the Value Proposition block and the Customer Segments block by adding 1 point in the Gain Creator section and 4 points in the Pain Reliever section.

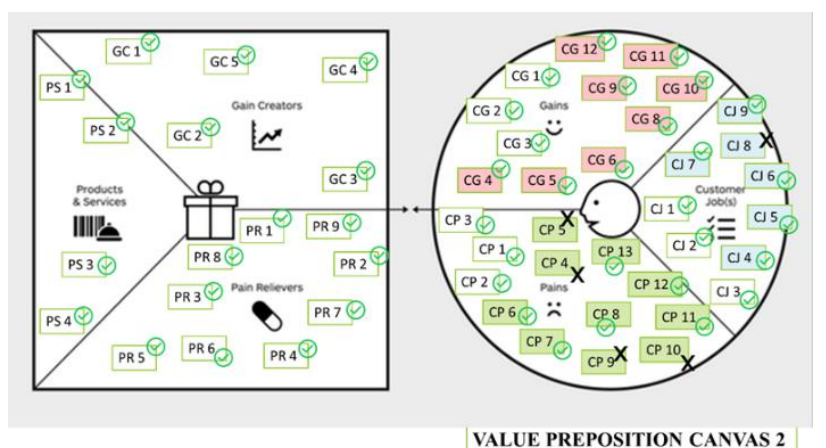

Fig. 1 Value Proposition Canvas 2

Based on Table 1, the one of the values added in the Value Mapping or Value Proposition section is BEETEA suitability, which is already quite attractive to consumers and contains information needed by consumers for the product which is attached to the Customer Gain section. The addition of variety of flavors, a freshness aroma, an increase on color thickness of the tea that better reflects the color of beets, and also the addition of product features where the product needs to be added to the tea bag straps for easier consumption.

Table 1. New Value Mapping for BEETEA's Product

\begin{tabular}{|l|l|}
\hline \multicolumn{2}{|c|}{ List of Beetea's New Value Mapping Style } \\
\hline GC 5 & $\begin{array}{l}\text { Has an attractive packaging and includes } \\
\text { information that needs to be known by consumers. }\end{array}$ \\
\hline PR 6 & $\begin{array}{l}\text { Add a variety of flavors that are more diverse than } \\
\text { the original beet taste }\end{array}$ \\
\hline PR 7 & $\begin{array}{l}\text { Add a freshness into the aroma to the aroma besides } \\
\text { the original beet }\end{array}$ \\
\hline PR 8 & $\begin{array}{l}\text { Thickens the color of beet tea to bring out an } \\
\text { attractive color for consumers }\end{array}$ \\
\hline PR 9 & $\begin{array}{l}\text { Adds features for consumers ease, such as tea bag } \\
\text { straps. }\end{array}$ \\
\hline
\end{tabular}

\section{REFERENCES}

[1] Sanlier, N. Gokcen, Busra B. Altug, M. 2018. Tea Consumption and Disease Correlations. Ankara (TUR): Journal of Trends in Food Science \& Technology 78 (2018), 95-106.

[2] De-Heer, N.E.A. Twumasi, P. Tandoh, M.A. Ankar-Brewoo, G. Odiro, I. 2013. Formulation and Sensory Evaluation of Herb Tea From Moringa Oleifera, Hibiscus Sabdariffa and Cymbopongon Citratus. North Labone (GH): Journal of Ghana Science Assoc. Vol. 15 No. 1

[3] Fu, Y. Yang, JC. Cunningham. Antony BT, Alexandra MZ, Yu. Y, Huaying. L, Jianwen. Yang, X. 2018. A Billion Cups: The Diversity, Traditional Uses, Safety Issues snd Potential of Chinese Herbal Teas. Journal of Ethnoprahmacology (2018).

[4] Rahmawati R. 2012. Budidaya Rosella Strategi Memanen Uang dalam 4 Bulan. Yogyakarta (ID): Pustaka Baru Press.

[5] Ravikumar, C. 2014. Review on Herbal Teas. Chennai (IN): Journal of PharmaceuticalSciences and Research Vol. 6(5), 236-238.

[6] Crawford MC, DiBenedetto, AC 2015. New Products Management 11th Edition. New York (USA): McGraw-Hill Education.

[7] Osterwalder, A, Pigneur, Y. Bernarda, G. Smith, A. 2014. Value Proposition Design. Canada (USA): Jhon Wiley \& Sons, Inc. 